\title{
Leaf tissues degradation of signalgrass hay pretreated with urea and submitted to in vitro digestion
}

\author{
Kátia Fernanda Gobbi ${ }^{1}$, Rasmo Garcia ${ }^{2}$, Marília Contin Ventrella ${ }^{3}$, Américo Fróes Garcez Neto ${ }^{4}$, \\ Odilon Gomes Pereira ${ }^{2}$
}

\author{
1 Programa de Pós-graduação em Zootecnia - UFV. \\ 2 Departamento de Zootecnia - UFV. \\ ${ }^{3}$ Departamento de Biologia Vegetal - UFV. \\ ${ }^{4}$ Escola de Medicina Veterinária/UFBA, Bolsista Pós-Doc - FAPESB.
}

\begin{abstract}
An experiment using signalgrass hay treated with increasing urea levels $(0,20,40$, and $80 \mathrm{~g} / \mathrm{kg}$ of dry matter), and submitted to in vitro digestion times $(0,6,12,24$ or 72 hours) was conducted to evaluate the effects of ammoniation rates and digestion times on leaf blade tissue degradation. A completely randomized design with a $4 \times 5$ factorial treatment arrangement, with three replicates was used. Data were submitted to multivariate analysis. Urea-treated hay presented smaller proportion of remaining tissues measured in leaf blades cross-sections after in vitro digestion. Tissues more affected by urea treatment degradation were parenchyma bundle sheath and sclerenchyma. The hay treated with $80 \mathrm{~g}$ urea/ $\mathrm{kg} \mathrm{DM}$ and in vitro digested for 24 or 72 hours showed smallest proportion of tissues with thick and lignified cell walls such as parenchyma bundle sheath and sclerenchyma. The treatment with urea also reduced the time necessary to tissue degradation. The urea-treated hay in vitro digested for 12 hours, showed the same tissue proportion found in untreated hay submitted to 24 or 72 hours of in vitro digestion. The epidermis and lignified vascular tissue showed the smallest degradation following in vitro digestion. Results indicated that treatment of signalgrass hay with urea contributed to cell wall structure disruption, enhancement of tissues microbial degradation and reduction of the time necessary to digestion.
\end{abstract}

Key Words: ammoniation, Brachiaria decumbens, $\mathrm{C}_{4}$ grass, histological analyses, leaf anatomy

\section{Degradação de tecidos foliares de feno de braquiária tratado com uréia e submetido à digestão in vitro}

\begin{abstract}
RESUMO - Um experimento utilizando feno de Brachiaria decumbens tratado com níveis crescentes de uréia $(0,20$, 40 e $80 \mathrm{~g} / \mathrm{kg}$ de MS) e submetido a diferentes tempos de digestão in vitro (0,6,12, 24 ou 72 horas), foi conduzido com o objetivo de se avaliar quais tecidos foliares têm a degradação mais afetada pela amonização e digestão. Adotou-se o delineamento experimental inteiramente casualizado, num arranjo fatorial $4 \times 5$, com três repetições. Os dados foram submetidos à análise multivariada. O feno tratado com uréia apresentou a menor proporção de tecidos remanescentes após a digestão in vitro. Os tecidos que tiveram a degradação mais afetada pela amonização foram a bainha do feixe vascular e o esclerênquima. O feno tratado com $80 \mathrm{~g}$ uréia/kg MS e submetido à digestão in vitro por 24 ou 72 horas apresentou a menor proporção de tecidos com parede celular espessa e lignificada, como bainha do feixe vascular e esclerênquima. O tratamento com uréia também reduziu o tempo necessário para degradação dos tecidos foliares. O feno tratado com uréia e submetido a 12 horas de digestão apresentou a mesma proporção de tecidos que o feno não-tratado e submetido a 24 ou 72 horas de digestão in vitro. A epiderme e o tecido vascular lignificado apresentaram menor degradação após a digestão in vitro. Os resultados indicaram que o tratamento com uréia contribuiu para a desestruturação da parede celular, aumentando a degradação microbiana dos tecidos e reduzindo o tempo necessário para a sua digestão.
\end{abstract}

Palavras-chave: amonização, análises histológicas, anatomia foliar, Brachiaria decumbens, gramínea $\mathrm{C}_{4}$

\section{Introduction}

Signalgrass (Brachiaria decumbens Stapf.) is a low to moderately high growing perennial rhizomatous/ stoloniferous tropical grass widely used in Brazil (Kretschmer
\& Pitman, 2001). It yields annually approximately $30 \mathrm{t} / \mathrm{ha}$ of dry matter (DM) (Silva, 1993; Daher et al., 2002), but not all of this can be utilized by grazing animals due to the high stem:leaf ratio and to the low digestibility of mature swards. 
Hay produced from tropical grasses, harvested at the reproductive phase, can be an alternative as roughage source in periods of forage shortage. This material, however, presents limiting characteristics to its consumption and use by ruminants, such as the high cell wall content, high levels of neutral detergent fiber (NDF), acid detergent fiber (ADF) and lignin, and low availability of nitrogen compounds and dry matter digestibility (Reis et al., 2001).

Forage cell walls can be considered the main source of energy for ruminants, however, the types of linkage between polysaccharides, wall thickness and lignin deposition are factors that can increase its resistance to rumen degradation, and consequently reduce its energy availability (Wilson, 1994).

Studies carried out with forage grasses under in vitro digestion demonstrate that different plant tissues present differentiated digestion rates. These tissues can be classified in descending order according to digestion easiness as following: mesophyll, phloem, parenchyma bundle sheath, epidermis, sclerenchyma and lignified vascular tissue (Akin, 1989; Wilson, 1993).

According to Wilson (1997), the characteristic anatomical structure of $\mathrm{C}_{4}$ grasses, such as signalgrass, with high proportion of lignified vascular tissue, sclerenchyma and parenchyma bundle sheath, which present thick and many times lignified cell walls, impair the nutritional value of these plants.

The treatment of roughages with chemical products that are sources of ammonia, urea for instance, can be used as alternative to improve the nutritional value and the digestibility of such materials. Ammonia can cause disruption of the cell wall structure allowing a faster fragmentation of the ingested material and improving rumen microorganism efficiency in degrading food particles, increasing its use by the animals (Goto \& Yokoe, 1996).

Histological/anatomical studies can be used to evaluate the characteristics of tissues during digestion in order to elucidate the factors affecting forage degradation by rumen microorganisms, and to explain the effect of some chemical treatments, such as ammoniation, on the improvement of roughage quality, complementing the information obtained from chemical and biological analyses.

An experiment was conducted aiming to evaluate the effects of ammoniation rates and digestion times on signalgrass leaf blade tissue degradation.

\section{Material and Methods}

The experiment was carried out in the Department of Animal Science and Plant Biology at the Federal University of Viçosa (UFV), in Viçosa-MG, from December 12, 2002 to January 16, 2003. The hay used in the experiment was obtained from a mature sward of signalgrass, in tropical conditions of Minas Gerais State, Brazil, and contained $54 \mathrm{~g}$ crude protein $(\mathrm{CP})$ and $878 \mathrm{~g} \mathrm{NDF} / \mathrm{kg}$ DM.

A completely randomized design was used, in a $4 \times 5$ (four urea levels and five digestion times) factorial arrangement, with three replicates. Treatments consisted of hay ammoniation with urea levels of $0,20,40$ and $80 \mathrm{~g} /$ $\mathrm{kg} \mathrm{DM}$ and the digestion times $0,6,12,24$, and 72 hours, to evaluate the in vitro digestion of different plant tissues.

The amounts of urea used for hay ammoniation were calculated according to the amount of hay to be treated $(2 \mathrm{~kg})$ and to the dry matter content of the material. Urea was applied as aqueous solution to elevate hay moisture to $300 \mathrm{~g}$ of water $/ \mathrm{kg}$ DM. Urea was diluted in water and solutions were poured over the hay in a heavy-duty plastic bag, with a watering can. After mixing, air was removed from the bags by compression. It was prepared three bags for each urea treatment, forming twelve experimental units.

Bags were sealed and stored in a shelter for 35 days and, at the end of this period, the bags were opened and aerated for 24 hours, so the non-reacting ammonia with the material was eliminated.

The sampling for histological evaluations was carried out after homogenizing the material, collecting the second youngest fully expanded leaf blades. For each experimental unit, two leaf blades were collected.

Segments of approximately $5 \mathrm{~mm}$ of length were sampled from the midpoint of the leaf blades and soaked into a 2.3 M sucrose solution for 12 hours for cryopreservation. The leaf blade segments were embedded in tissue freezing medium (Leica Instruments, Germany) and cut at 16-mm thick cross-sections using a cryomicrotome. The thinsections were dropped on the microscope slides mounted with a transparent double-stick tape, according to the technique proposed by Akin (1982).

The in vitro digestibility assay followed the procedure proposed by Tilley \& Terry (1963) and modified by Akin (1982). Rumen fluid was collected from a fistulated steer, fed with signalgrass hay, and diluted 1:2 with McDougall buffer equilibrated at $39^{\circ} \mathrm{C}$ with $\mathrm{CO}_{2}$ gassing for 30 minutes. The microscope slides with adherent thin-sections were transferred to vessels with $50 \mathrm{~mL}$ of rumen fluid inoculum equilibrated at $39^{\circ} \mathrm{C}$. Vessels were sealed under $\mathrm{CO}_{2}$ with rubber stoppers with Bunsen valves and placed in an incubator at $39^{\circ} \mathrm{C}$. In non-digestion treatment (ND), the leaf blades were maintained in tubes containing only the McDougall buffer until the end of the digestibility assay (Akin et al., 1973). 
At the end of each digestion period the leaf blades were removed from the tubes and washed in distilled water. The cuts were stained with astra blue and basic fuchsin, mounted on glycerine jelly, and the microscope slides covered with coverslips.

Digitized images of the leaf-blade cross-sections were obtained with a camcorder camera coupled to a photomicroscope and a computer.

After the in vitro digestion, the area and the linear measures of each remaining tissue in the leaf cross-sections were calculated using the Image-Pro Plus 4.1 software. In an area between two first-order vascular bundles, the following anatomical characteristics were determined: the area of the mesophyll (chlorophyllian and fundamental parenchyma + bulliform cells), adaxial epidermis, abaxial epidermis, lignified vascular tissue (xylem + associated fibers), phloem, and sclerenchyma, and the length $(\mu \mathrm{m})$ of the outer, radial and inner walls of the parenchyma bundle sheath cells. The area data were transformed to percentage, in relation to the total area of the cross-section.

The data referring to the proportion of remaining tissues in the leaf blade cross-sections after in vitro digestion were statistically analyzed using the Principal Component Analysis (PCA).

PCA has two main objectives. The first is to reduce the number of variables to a smaller number of new derived variables that summarize the original information ( $\mathrm{Y} 1$ and
Y2), retaining the bulk of relevant information and discarding noise. The second objective is to reveal patterns in the data that could not be found by analyzing each variable separately (Quinn \& Keough, 2002).

This method arranges the treatments along axes of variation. In PCA, the first axis represents the direction of maximum variation in the data; the second axis displays the largest amount of independent variation, and so on. The biplots can be used to represent simultaneously the variation among the treatments and the variables on the same diagram (Kelly \& Basford, 2000).

The statistical analysis was carried out using the procedures of principal component analysis (PRINCOMP) from the SAS/STAT software (1990).

\section{Results and Discussion}

Multivariate analysis of data indicated a general reduction of tissue proportion in response to urea levels and digestion times (Table 1). Figures 1 and 2 show examples of the leaf blade cross-sections anatomy in signalgrass hay non-treated or treated with $80 \mathrm{~g}$ urea/kg DM under different times of in vitro digestion.

Due to the high value of the information in Y1 (79.27\%), this first principal component was enough to explain the contribution of the original variables, for the three replicates of the twenty treatments. The information held in the second

Table 1 - Mean values of tissues proportion in leaf blades of non-treated and urea-treated signalgrass hay after in vitro digestion Mesophyll (MES); phloem (PHL); lignified vascular tissue (LVT); sclerenchyma (SCL); abaxial epidermis (EPab); adaxial epidermis (EPad); outer, inner and radial cell wall parenchyma bundle sheath (PBSo, PBSi, PBSr)

\begin{tabular}{|c|c|c|c|c|c|c|c|c|c|c|}
\hline \multicolumn{2}{|c|}{ Treatment } & \multirow[t]{2}{*}{$\operatorname{MES}(\%)^{*}$} & \multirow[t]{2}{*}{ PHL (\%) } & \multirow[t]{2}{*}{ LVT (\%) } & \multirow[t]{2}{*}{ SCL (\%) } & \multirow[t]{2}{*}{ EPab (\%) } & \multirow[t]{2}{*}{ EPad (\%) } & \multirow[t]{2}{*}{ PBSo $(\mu \mathrm{m})$} & \multirow[t]{2}{*}{ PBSi $(\mu \mathrm{m})$} & \multirow[t]{2}{*}{$\operatorname{PBSr}(\mu \mathrm{m})$} \\
\hline Urea (\%) & Digestion (hours) & & & & & & & & & \\
\hline 0 & $\mathrm{ND}^{* *}$ & 49,86 & 2,21 & 5,64 & 8,55 & 6,15 & 3,27 & 2,47 & 1,37 & 1,03 \\
\hline 0 & 6 & 46,74 & 1,61 & 5,48 & 7,55 & 5,94 & 2,52 & 2,33 & 1,29 & 0,98 \\
\hline 0 & 12 & 16,81 & 0,00 & 5,27 & 6,04 & 6,34 & 2,11 & 2,37 & 1,26 & 0,87 \\
\hline 0 & 24 & 5,73 & 0,00 & 5,45 & 3,46 & 6,27 & 1,53 & 1,70 & 0,84 & 0,38 \\
\hline 0 & 72 & 7,41 & 0,00 & 4,96 & 2,76 & 5,97 & 1,52 & 1,52 & 0,90 & 0,38 \\
\hline 2 & ND & 50,88 & 1,65 & 4,83 & 6,64 & 6,23 & 4,15 & 2,35 & 1,14 & 0,96 \\
\hline 2 & 6 & 47,57 & 1,35 & 4,39 & 5,42 & 6,10 & 4,35 & 2,44 & 1,22 & 0,87 \\
\hline 2 & 12 & 17,46 & 0,00 & 3,96 & 3,67 & 5,06 & 3,06 & 1,59 & 1,17 & 0,76 \\
\hline 2 & 24 & 7,75 & 0,00 & 3,88 & 1,65 & 3,84 & 2,31 & 1,57 & 0,66 & 0,41 \\
\hline 2 & 72 & 3,47 & 0,00 & 3,67 & 1,00 & 4,01 & 2,41 & 1,37 & 0,45 & 0,36 \\
\hline 4 & ND & 50,63 & 1,85 & 4,31 & 6,75 & 5,40 & 4,25 & 2,39 & 1,14 & 0,98 \\
\hline 4 & 6 & 48,81 & 1,40 & 4,61 & 6,61 & 5,60 & 4,21 & 2,34 & 1,16 & 0,99 \\
\hline 4 & 12 & 16,85 & 0,00 & 4,04 & 2,68 & 5,25 & 2,91 & 2,29 & 1,02 & 0,88 \\
\hline 4 & 24 & 9,66 & 0,00 & 3,73 & 0,92 & 4,36 & 2,36 & 1,68 & 0,57 & 0,37 \\
\hline 4 & 72 & 5,28 & 0,00 & 3,40 & 1,11 & 3,45 & 2,34 & 1,36 & 0,48 & 0,26 \\
\hline 8 & ND & 47,63 & 1,97 & 4,78 & 7,80 & 6,08 & 4,23 & 2,50 & 1,23 & 1,03 \\
\hline 8 & 6 & 45,32 & 0,88 & 4,63 & 7,55 & 5,99 & 4,26 & 2,54 & 1,28 & 0,92 \\
\hline 8 & 12 & 13,08 & 0,00 & 3,92 & 5,07 & 4,76 & 2,83 & 1,43 & 0,76 & 0,48 \\
\hline 8 & 24 & 8,09 & 0,00 & 3,34 & 1,08 & 2,52 & 1,69 & 1,13 & 0,36 & 0,19 \\
\hline 8 & 72 & 2,16 & 0,00 & 3,17 & 1,33 & 1,74 & 1,54 & 0,91 & 0,25 & 0,12 \\
\hline
\end{tabular}

${ }^{*}(\%)=$ percentage of the tissue in relation to leaf blade cross-section total area; **non-digestion. 

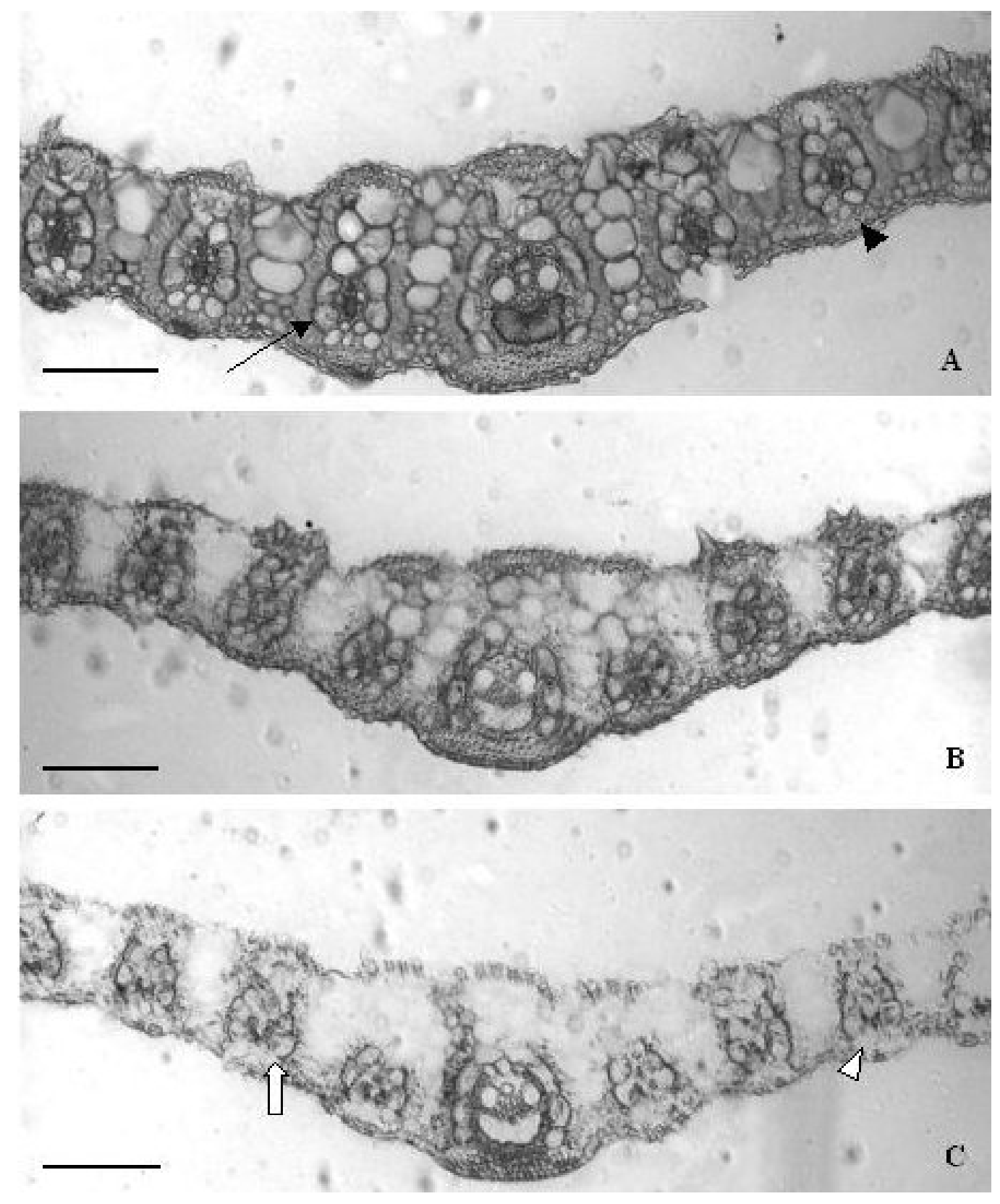

Figure 1 - Leaf blade cross sections of signalgrass hay non-treated with urea and submitted to in vitro digestion. Arrows indicate PBS intact $(\rightarrow)$, sclerenchyma intact $(\triangleright)$, PBS partially digested $(\Rightarrow)$ and sclerenchyma partially digested $(\triangleright)$. A) C ND; B) C 12h; C) C 72h. Bar $=100 \mu \mathrm{m}$. (C = control; $\mathrm{h}=$ hours digestion; ND = non-digestion $)$.

principal component (Y2) was $12.22 \%$ (Table 2), which was considered low and therefore insufficient to explain the contribution of the original variables analyzed in the treatments.

The variables of principal component Y1 with larger discriminatory power in descending order of importance were: length of the radial, inner and outer cell walls in the parenchyma bundle sheath; area of the sclerenchyma; mesophyll; phloem; abaxial and adaxial epidermis and lignified vascular tissue.
The largest discriminatory power found for the cell wall length in the parenchyma bundle sheath (PBS) and area of the sclerenchyma indicates that these variables presented the largest variation as a function of the treatments, with their pattern being used for the interpretation of the results from the experimental assay.

The graphic dispersion analysis of the principal components in Figure 3 allowed the formation of groups among the treatments showing the largest similarity for tissue characteristics in leaf blade cross-sections, as follows: 

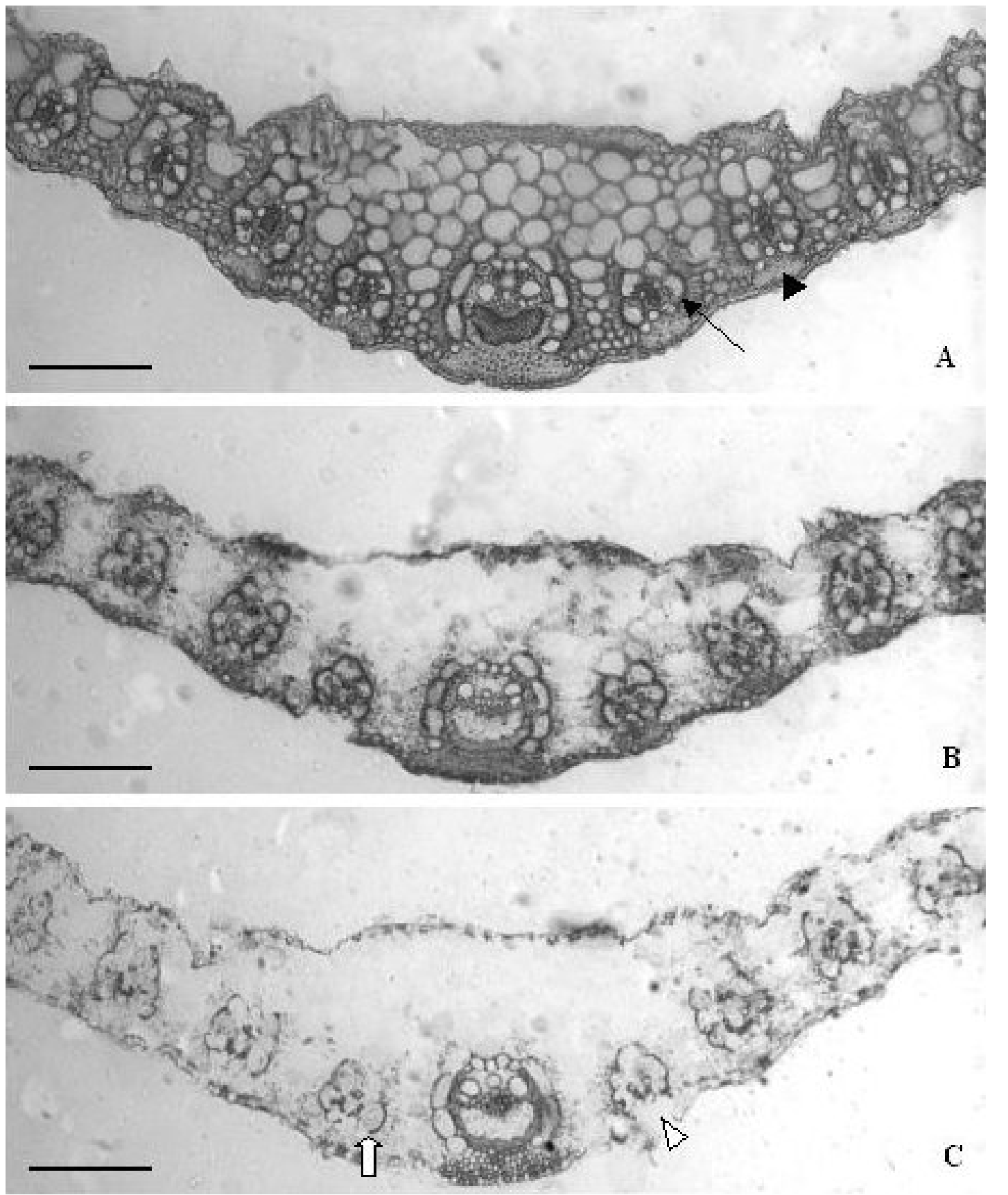

Figure 2 - Leaf blade cross sections of signalgrass hay treated with $80 \mathrm{~g}$ urea/kg DM and submitted to in vitro digestion. Arrows indicate PBS intact $(\rightarrow)$, sclerenchyma intact $(\triangleright)$, PBS partially digested $(\Rightarrow)$ and sclerenchyma partially digested $(\triangleright)$. A) U80 ND; B) U80 12h; C) U80 72h. Bar $=100 \mu \mathrm{m}$. ( $\mathrm{h}=$ hours digestion; ND = non-digestion; $\mathrm{U}=$ urea).

Group I - non-treated hay or treated with 20, 40 and $80 \mathrm{~g}$ urea/kg DM, non-digested or under 6 hours of in vitro digestion; Group II - hay treated with 20, 40 and $80 \mathrm{~g}$ urea/ $\mathrm{kg}$ DM, under 24 or 72 hours of in vitro digestion; Group III - non-treated hay under 12, 24 and 72 hours of digestion and treated hay with 20,40 and $80 \mathrm{~g}$ urea/kg DM under 12 hours of in vitro digestion.

For group I, from principal component $\mathrm{Y} 1$, regardless of the urea level, there was great amount of remaining tissue in the leaf cross-sections up to 6 hours of digestion, mainly PBS cell walls and sclerenchyma, since these variables showed large correlation coefficient. Within 6 hours of digestion, tissue degradation was minimum, with degradation starting only on tissues with cells of thin primary wall like phloem and mesophyll, such as found by Akin et al. (1983) working with Panicum species.

For group II, all treatments with at least $20 \mathrm{~g}$ urea $/ \mathrm{kg}$ DM and 24 hours of digestion gave high tissue degradation 
Table 2 - Correlation between each measured variable (anatomical characteristics) and the first two axes of a principal component analysis $\left(\mathrm{Y}_{1}\right.$ and $\left.\mathrm{Y}_{2}\right)$. Percentage variation and cumulative percentage variation of the two axes, and ordering of variables according to its discriminatory power

\begin{tabular}{|c|c|c|c|c|}
\hline Variable & $\mathrm{Y}_{1}$ & Order & $\mathrm{Y}_{2}$ & Order \\
\hline Mesophyll (\%) & 0,934 & 5 & $-0,305$ & 5 \\
\hline Phloem (\%) & 0,857 & 6 & $-0,307$ & 4 \\
\hline Lignified vascular tissue $(\%)$ & 0,751 & 9 & 0,615 & 1 \\
\hline Adaxial epidermis $(\%)$ & 0,845 & 7 & 0,446 & 3 \\
\hline Abaxial epidermis (\%) & 0,785 & 8 & $-0,542$ & 2 \\
\hline Inner cell wall parenchyma bundle sheath $(\mu \mathrm{m})$ & 0,954 & 2 & 0,011 & 9 \\
\hline Percentage variation $(\%)$ & 79,27 & & 12,22 & \\
\hline Cumulative percentage variation $(\%)$ & 79,27 & & 91,49 & \\
\hline
\end{tabular}

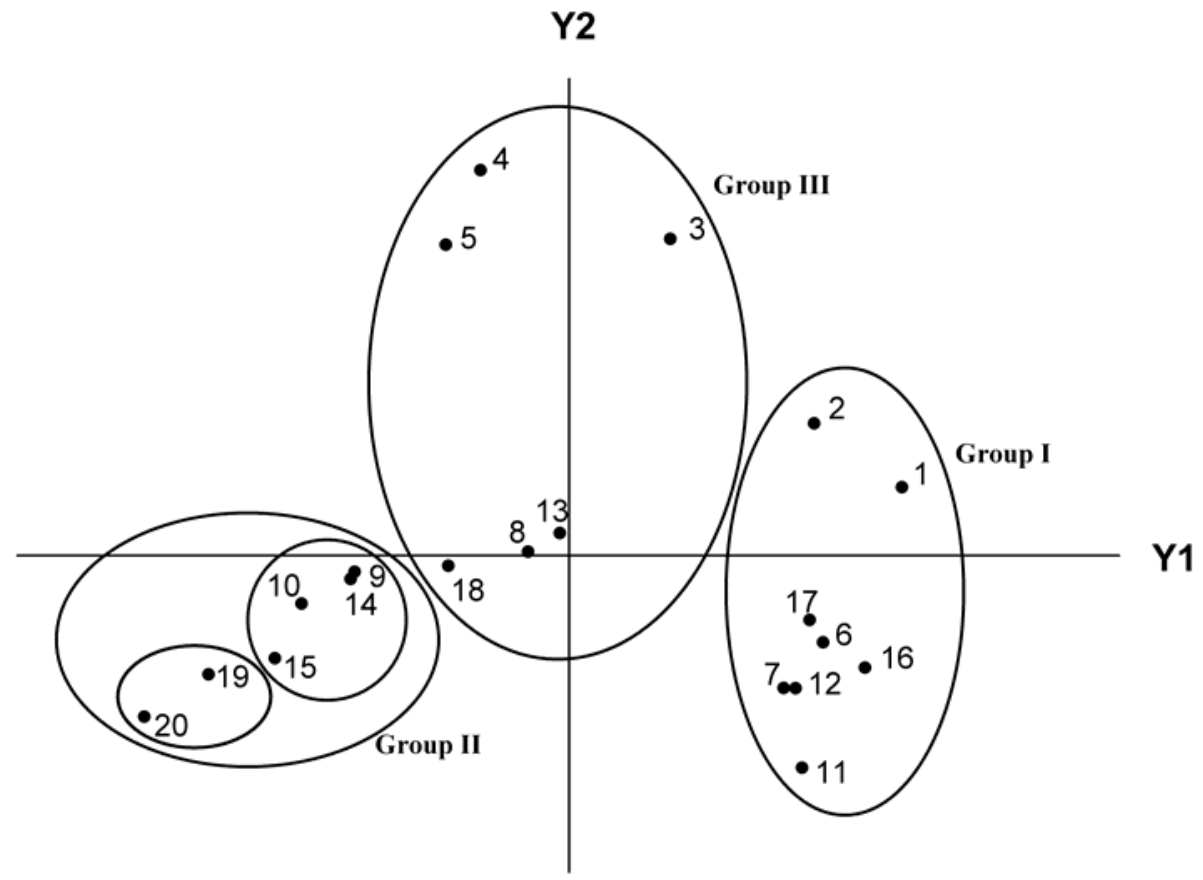

Figure 3 - Biplot of principal components $\mathrm{Y} 1$ and $\mathrm{Y} 2$ from the ordination of 20 treatments using 9 variables (see Table 2). Treatments: 1) C ND; 2) C 6h; 3) C 12h; 4) C 24h; 5) C 72h; 6) U20 ND; 7) U20 6h; 8) U20 12h; 9) U20 24h; 10) U20 72h; 11) U40 ND; 12) U40 6h; 13) U40 12h; 14) U40 24h; 15) U40 72h; 16) U80 ND; 17) U80 6h; 18) U80 12h; 19) U80 24h; 20) U80 72h. (C = control; $\mathrm{h}=$ hours digestion; $\mathrm{ND}=$ non-digestion; $\mathrm{U}=$ urea).

(Figure 3). The highest degradation rate, mainly PBS cell walls and sclerenchyma, occurred in treatments with $80 \mathrm{~g}$ urea $/ \mathrm{kg}$ DM. This suggests that the ammonia produced from urea caused fragility in tissue cell wall increasing degradation.

The use of ammonia for treating roughage can cause a disruption of the cell wall by breaking the linkages between polysaccharides and between these and lignin, increasing hydration and cell wall fragility. This disruption would promote the access of rumen microorganisms to the cell wall surface, increasing tissue degradation in the rumen and food intake by the animals (Goto \& Yokoe, 1996). This partly explains the increase in digestion of tissues with thick and lignified wall as PBS cells and sclerenchyma found in hay treated with urea.

The effect of ammonia on the cell wall of plant tissues, breaking intermolecular linkages and dissolving their compounds, was confirmed by chemical analysis of the hay used in this experiment, which showed a reduction in the levels of NDF, ADF and cellulose in the material treated with urea (Gobbi et al., 2005).

The $\mathrm{C}_{4}$ grasses, such as signalgrass, have high efficiency of nitrogen use, which results in low protein content in the plants. This lower protein level is usually inadequate to supply the demands of rumen microorganisms to ensure maximum efficiency (Wilson \& Hattesley, 1983). 
Urea is considered a non-proteic nitrogen source and its use in signalgrass hay might also have contributed to supply the needs of rumen microorganisms, increasing their efficiency in tissue digestion, since the total nitrogen content in the treated hay increased linearly as a function of the urea levels (Gobbi et al., 2005).

The PBS cells contain large protein and starch proportion, being considered an important source of easily digestible compounds in tropical grasses. These cells concentrate most of the rubisco (ribulose-1,5-bisphosphate carboxylase/oxygenase) enzyme, which represents approximately $50 \%$ of the soluble protein in $\mathrm{C}_{4}$-grass leaves (Wilson, 1997). The PBS cell wall disruption, caused by the urea treatment, can contribute to availability of easily digestible compounds contained in these cells for rumen microorganisms.

The cell wall fragility and the significant increase in the in vitro digestibility of the ammoniated material were also reported by Goto et al. (1993) and Leal et al. (1994), working with sorghum and barley straw, respectively. Shen et al. (1999) reported that the ammoniation of rice straw caused parenchyma expansion and partial cell wall breaking of vascular tissue, enhancing straw digestibility.

The treatments comprising group III (Figure 3 ) gave an intermediate amount of remaining tissues after in vitro digestion. Twelve hours of digestion for the material treated with 20, 40 and $80 \mathrm{~g}$ urea/ $\mathrm{kg} \mathrm{DM}$ and 12, 24 and 72 hours for the non-treated material were not enough to ensure effective tissue degradation, mainly PBS cells and sclerenchyma.

From the results of group III, it can also be concluded that the treatment with urea contributed to reduce the time needed for tissue degradation. Within 12 hours of digestion the degradation of hay treated with urea was equivalent to the degradation of the non-treated material under 24 or 72 hours of digestion. This can be explained by the cell wall weakening caused by ammonia, making it possible the access of rumen microorganisms and increasing the microbial colonization on the tissues (Goto et al., 1993).

The variables with smaller discriminatory power in the principal component $\mathrm{Y} 1$ were the epidermis and the lignified vascular tissue (LVT) (Table 2). These tissues had lower degradation during the digestibility assay, not undergoing significant changes caused by urea or digestion times. The lignified vascular tissue has cells with thick and quite lignified secondary wall, which hampers its degradation by rumen microorganisms (Akin, 1989; Wilson, 1993). The tangential outer walls of epidermal cells become thick and lignified in mature plants, being even covered by the cuticle. These characteristics can make the outer surface of the epidermis inaccessible to rumen microorganisms preventing its degradation.

\section{Conclusions}

The treatment of signalgrass hay with urea affected the structure of cell wall of tissues, mainly PBS cells and sclerenchyma. This might have contributed to increase the availability of cell-wall polysaccharides to rumen microorganisms, increasing the digestion and reducing the time needed for the degradation of these tissues.

\section{Literature Cited}

AKIN, D.E. Section to slide technique for study of forage anatomy and digestion. Crop Science, v.22, p.444-446, 1982.

AKIN, D.E. Histological and physical factors affecting digestibility of forages. Agronomy Journal, v.81, p.17-25, 1989.

AKIN, D.E.; AMOS, H.E.; BARTON, F.E. et al. Rumen microbial degradation of grass tissue by scanning electron microscopy. Agronomy Journal, v.65, p.825-828, 1973.

AKIN, D.E.; WILSON, J.R.; WINDHAM, W.R. Site and rate of tissue digestion in leaves of $\mathrm{C}_{3}, \mathrm{C}_{4}$ and $\mathrm{C}_{3} / \mathrm{C}_{4}$ intermediate Panicum species. Crop Science, v.23, p.147-155, 1983.

DAHER, R.F.; MALDONADO, H.; GOMES, F.F. et al. Introdução e avaliação de 12 gramíneas forrageiras em campos dos Goytacazes, RJ. Ciência Agrotécnica, p.1575-1579, 2002 (edição especial de dezembro).

GOBBI, K.F.; GARCIA, R.; GARCEZ NETO, A.F. et al. Composição química e digestibilidade in vitro do feno de Brachiaria decumbens Stapf. tratado com uréia. Revista Brasileira de Zootecnia, v.34, n.3, p.720-725, 2005.

GOTO, M.; YOKOE, Y. Ammoniation of barley straw. Effect on cellulose crystallinity and water-holding capacity. Animal Feed Science and Technology, v.58, p.239-247, 1996.

GOTO, M.; YOKOE, Y.; TAKABE, K. et al. Effects of gaseous ammonia on chemical and structural features of cell walls in spring barley straw. Animal Feed Science and Technology, v.40, p.207-221, 1993

KELLY, A.M.; BASFORD, K.E. Pattern analysis in grassland and animal production systems. In: t' MANNETJE, L.; JONES, R.M. (Eds.) Field and laboratory methods for grassland and animal production research. Wallingford: CAB International, 2000. p.9-28.

KRETSCHMER, A.E., JR; PITMAN, W.D. Germplasm resources of tropical forage grasses. In: SOTOMAYOR-RÍOS, A.; PITMAN, W.D. (Eds.) Tropical forage plants: developmen and use. Boca Raton: CRC Press, 2001. p.27-40.

LEAL, M.; SHIMADA, A.; HERNÁNDEZ, E. The effect of $\mathrm{NH}_{3}$ and/or $\mathrm{SO}_{2}$ on the compositional and histological characteristics of sorghum stover. Animal Feed Science and Technology, v.47, p.141-150, 1994

QUINN, G.P.; KEOUGH, M.J. Experimental design and data analysis for biologists, 1.ed. Cambridge: Cambridge University Press, 2002. 537p.

REIS, R.A.; RODRIGUES, L.R.A.; PEREIRA, J.R.A. et al Composição química e digestibilidade de fenos tratados com amônia anidra ou uréia. Revista Brasileira de Zootecnia, v.30, n.3, p.666-673, 2001.

STATISTICAL ANALYSIS SYSTEM - SAS. SAS/STAT user's guide. Version 6. 4.ed. Cary: Statistical Analysis System Institute, 1990. 846p. 
SHEN, H.S.; SUNDSTOL, F.; ENG, E.R. et al. Studies on untreated and urea-treated rice straw from three cultivation seasons: 3 . Histological investigations by light and scanning electron microscopy. Animal Feed Science and Technology, v.80, p.151-159, 1999.

SILVA, S.C. Manejo de forrageiras dos gêneros Brachiaria, Cynodon e Setaria. In: PEIXOTO, A.M.; MOURA, J.C.; FARIA, V.P. (Eds.) Volumosos para bovinos. Piracicaba: Fundação de Estudos Agrários Luiz de Queiroz, 1993. p.29-58.

TILLEY, J.M.A.; TERRY, R.A. A two stage technique for the in vitro digestion of forage crops. Journal of the British Grassland Society, v.18, n.2, p.104-111, 1963.

WILSON, J.R. Organization of forage plant tissues. In: JUNG, H.G.; BUXTON, D.R.; HATFIELD, R.D. et al. (Eds.) Forage cell wall structure and digestibility. Madison: ASA-CSSA-SSSA, 1993. p.1-32.

WILSON, J.R. Cell wall characteristics in relation to forage digestion by ruminants. Journal of Agricultural Science, v.122, p.173$182,1994$.

WILSON, J.R. Structural and anatomical traits of forages influencing their nutritive value for ruminants. In: SIMPÓSIO INTERNACIONAL SOBRE PRODUÇÃO ANIMAL EM PASTEJO, 1997, Viçosa, MG. Anais... Viçosa, MG: UFV, 1997. p.173-208.

WILSON, J.R.; HATTERSLEY, P.W. In vitro digestion of bundle sheath cells in rumen fluid and its relation to the suberized lamella and $\mathrm{C}_{4}$ photosynthetic type in Panicum species. Grass and Forage Science, v.38, p.219-223, 1983. 